DOI: $10.5800 / G T-2020-11-2-0483$

\title{
EXPERIMENTAL STUDY OF OBSERVABLE DEFORMATION PROCESS IN FAULT META-INSTABILITY STATE BEFORE EARTHQUAKE GENERATION
}

\author{
Yanshuang Guo, Yanqun Zhuo, Peixun Liu, Shunyun Chen, Jin Ma
}

State Key Laboratory of Earthquake Dynamics, Institute of Geology, China Earthquake Administration, Beijing, China

\section{HIGHLIGHTS:}

1. Fault meta-instability is a key observable deformation stage to identify seismic precursor information.

2. Local preslips or micro-ruptures happen in few segments of fault, but there is only one nucleation zone.

3. The preslip areas first occur in the segments of low volume strain, but fast instability of the fault starts in the high volume strain area.

ABSTRACT. According to the steady state of fault and energy balance, we provided a new idea to observe the precursors for a stressed fault. The meta-instability (or sub-instability) state of a fault is defined as the transition phase from peak stress to critical stress of fast instability (earthquake generation) during a full period of slow loading and fast unloading. The accumulative deformation energy begins to release in this stage. Identifying its deformation before fast instability would be beneficial to obtain premonitory information, and to evaluate the seismic risks of tectonic regions. In this study, we emphasized to analyze deformation process of the meta-instable stage with stain tensor data from a straight precut fault in granite at a slow loading rate, and observed the tempo-spatial features during the full deformation process of the fault. Two types of tectonic zones and instabilities occur on the stick-slip fault. The low- and high-value segments in the volume strain component appear along the fault strike with a load increment. The former first weakens and then becomes initial energy release segments; the latter forms strong stress-interlocking areas and finally turns into the initial region of fast instability. And there are two stages in the entire instable process of the fault: the initial stage is associated with the release of the low volume strain segments, which means fault pre-slips, slow earthquakes or weak earthquakes. The second one characterizes a strong earthquake through the release of high volume strain parts. The rupture acceleration in the first stage promotes the generation of the second. Moreover, fault instability contains two types of strain adjustments along the fault: the front-like strain change along the transition segments from low- to high- strain portions with volume strain release, and the compressive strain pulse of fault instability after the volume strain release extends to a certain range with loading increment. In laboratory experiments, the front-type strain occurs about 12 seconds before fast fault instability; the compressive pulse initiates within less than 0.1 second, and then the fault turns quickly into a dynamic strain adjustment, which appears quasi-synchronously between different measurement points, and, finally, an earthquake is generated.

KEYWORDS: fault meta-instability; deformation process; strain tensor; precursory information

FUNDING: The research is financially supported by the National Natural Science Foundation of China (grants No. 41911530111 and No. 41572181), the National Key R\&D Program of China (grant No. 2018YFC1503301) and the Basic Research Funds from Institute of Geology, China Earthquake Administration (grant No. IGCEA1203). 


\title{
ЭКСПЕРИМЕНТАЛЬНОЕ ИССЛЕДОВАНИЕ ДЕФОРМАЦИОННОГО ПРОЦЕССА НА РАЗЛОМЕ В МЕТАСТАБИЛЬНОМ СОСТОЯНИИ ПЕРЕД ЗЕМЛЕТРЯСЕНИЕМ
}

\author{
Юаншуан Гуо, Янцюнь Чжуо, Пэйксунь Лю, Шуньюнь Чен, Цзинь Ма
}

Государственная центральная лаборатория динамики землетрясений, Институт геологии, Администрация по землетрясениям Китая, Пекин, Китай

\section{ОСНОВНЫЕ МОМЕНТЫ:}

1. Метанестабильность разлома является ключевой наблюдаемой стадией деформации для идентификации информации о сейсмическом прекурсоре.

2. Локальные предварительные скольжения или микроразрывы происходят в нескольких сегментах разлома, но существует только одна зона зарождения.

3. Области предварительного проскальзывания сначала возникают в сегментах деформации с низким объемом, но быстрая нестабильность повреждения начинается в области деформации с большим объемом.

АНнотАЦия. Предлагается новый подход к выделению предвестников землетрясения в зоне разлома с высоким уровнем напряжений, опирающийся на понятия его устойчивого состояния и энергетического баланса. В условиях экспериментального воспроизведения модели прерывистого «stick-slip» в пределах полного цикла медленной нагрузки и быстрой разгрузки деформируемого образца с разрезом, имитирующим разлом, предельные состояния его метастабильности и метанестабильности при пиковом критическом напряжении определяются как переходная фаза от устойчивости к неустойчивости со спонтанной генерацией импульсной подвижки (т.е. генерации землетрясения). С переходом модельного разлома в состояние метанестабильности стартует процесс медленного, пространственно-дискретного, избирательного высвобождения накопленных на нем напряжений. Выявление этого процесса до его перехода в стадию быстрой нестабильности имеет важное прогнозное значение для превентивной оценки риска в тектонически активных регионах. В выполненном авторами экспериментальном исследовании проанализированы вариации тензора напряжений в нагруженном гранитном образце с прямолинейным разрезом в течение метанестабильной стадии, а также проведено наблюдение пространственно-временных особенностей этого параметра в течение всего процесса деформации модельного разлома.

Установлено, что по простиранию разлома имеют место сегменты с низкими и высокими значениями объемной деформации, которым соответствуют два типа нестабильности. Первые закладываются на участках с пониженной прочностью и становятся сегментами начального высвобождения энергии в начальную стадию нестабильности. Вторые, наоборот, характерны для участков упрочнения разлома, где происходит блокировка напряжений, и впоследствии превращаются в начальные области быстрой нестабильности.

В рамках процесса нестабильности разлома выделены две стадии. В первую стадию происходит реализация небольших медленных сдвиговых смещений на разломе в пределах сегментов первого типа, именуемых в литературе предсмещениями, низкочастотными, медленными или тихими землетрясениями и т.д. Сегментация развивается с ускорением, что способствует переходу деформационного процесса во вторую стадию, когда происходит быстрое динамической объединение сегментов обоих типов с реализацией большого смещения по разлому, что соответствует сильному землетрясению в природе.

В условиях нестабильности разлома зафиксированы два типа деформации вдоль его простирания: фронтальная миграция деформации вдоль сегментов первого типа при смещениях по ним к сегментам второго и импульс деформации сжатия после реализации объемной деформации после смещения, распространяющийся на определенное расстояние в условиях роста приложенной к образцу нагрузки. В выполненных экспериментах фронтальная деформация возникала примерно за 12 с до быстрой нестабильности разлома, а импульс сжатия начинается менее чем за 0.1 с до нее. Динамическая деформация на разломе проявляется квазисинхронно по простиранию разлома во всех точках измерения.

КЛЮЧЕВЫЕ СЛОВА: метанестабильность разлома; процесс деформации; тензор деформации; информация о предвестнике землетрясения

ФИНАНСИРОВАНИЕ: Исследование финансируется Национальным фондом естественных наук Китая (гранты № 41911530111 и № 41572181), Национальной ключевой программой исследований и разработок Китая (грант № 2018YFC1503301) и фондами фундаментальных исследований Института геологии Управления землетрясений Китая (грант № IGCEA1203). 


\section{INTRODUCTION}

Since the Brace and Byerlee's proposal [Byerlee, 1967, 1978; Brace, Byerlee, 1966, 1970] describing shallow earthquake mechanism with stick-slip phenomenon and Dieterich's description [Dieterich, 1978, 1979] of the sliding law with rate- and state- dependent friction constitute, the sliding friction feature of a simple fault has become one of the most important fields to extensively study earthquake mechanism, including theoretical analysis, laboratory experiment and field observation. Many researchers have paid more attentions to the instable process of fault friction and discussed occurrence conditions on stick-slip or stable slip, and their influence factors.

Some previous research results are far-reaching. For example, the change of friction strength involves a direct effect on sliding velocity, the constant $a$, and an indirect response $b$, with an exponential decay function that formulated the strengthening or weakening parameter during the transition phase of fault instability. The results reveal that a stable friction coefficient increases with loading velocity increment as the value of $a-b$ is positive, which means the velocity strengthening of fault, velocity weakening as $a-b$ becomes negative, conversely. And there is a critical stiffness [Ruina, 1983; Rice, Ruina, 1983; Scholz, 1988], which refers to a certain value that the periodic stick-slip event would appear when the system stiffness is smaller than this certain value. Otherwise, stable sliding occurs in the case of small disturbances. As $a-b$ is negative, the instability of fault slip nucleation is produced [Dieterich, 1986, 1992]. Thus, the value of $a-b$ during the steady state becomes an important criterion for determining sliding stability.

Based on the understanding above, many researchers studied the conditions and mechanism of weakening and strengthening of the fault zone under different temperatures, pressures, loading velocities and pore pressures, etc. For instance, Moore demonstrated that the serpentine containing talc is a factor to induce high-speed non-earthquake creep of San Andreas Fault [Moore, Rymer, 2007]; Rice [Rice, 2006] systematically studied its absolute and relative weakening process, the expansion effect resulted from fault instability, the influences from pore fluid to earthquake nucleation and dynamic earthquake rupture. Furthermore, other authors discussed the action of normal stress during frictional sliding and the problems about periodic-doubling and the chaotic properties of sliding [He, 2000, 2003; He et al., 2004, 2006, 2007]. After the Great Wenchuan Earthquake occurred in 2008, some researchers investigated its seismogenic conditions, and emphasized the effect of fault gouge and water to the fault instability under high-angle thrust faulting [Zhou, He, 2009]. These results above only answered what some probable conditions to result in earthquakes are, but concerned the precursor features of the great shock.

The precursor of an instable fault is one of the focuses in earthquake research, especially the nucleation process of fault stick-slip relative to seimogeneration. Small specimens (about $20 \mathrm{~mm}$ in diameter) were usually used under high temperature and high pressure for testing. In this case, an average parameter for a fault surface was taken as a single value discussing the constitution relationship of fault media. As the fault is not uniform in reality, a modified assumption has to be made for a better reflection of the reality. Therefore, some larger scales of biaxial experiments were carried out under confining (or lateral) pressure condition. These experiments characterized large specimens, and the common observations of the multiphysical fields provided some plausible clues for analyzing the distribution properties of earthquake precursors. On the base of experimental results [Peselnik et al., 1976; Dieterich, 1986, 1992; Ohnaka et al., 1987, 1997; Ohnaka, Kuwahara, 1990; Ohnaka, 1992] proposed the nucleation conception before fault instability and the relationship between pre-sliding scale and instability. They also pointed out that the nucleation is a shortterm and impending precursory of an earthquake, and emphasized that the instability is caused by fault weakening. Moreover, other authors discussed the nucleation process and nucleation phase in homogeneous and heterogeneous fault regarding to geometries and medium factors [Ma et al., 2002, 2003]. Ma found that the action on the friction stability from the heterogeneity of faults, and further proposed that the scales of the weakening fault segment would also affect fault instability. The large-scale of weakening section accorded with the rate- and state-law of friction and earthquake instability in accelerating sliding was finally caused by fault weakening. Furthermore, the wear of the fault zone, the roughness of the fault surface and the loading velocity were also studied in large-scale biaxial friction experiments [Aochi, Fukuyama, 2002; Fukuyama, 2009]. In addition, some authors simulated earthquake sliding velocity using rotation friction devices to study the mechanism with controlled weakening methods [Chang et al., 2012]. Meanwhile, Reches et al. noticed that melting due to friction heating and fault powder has an influence on fault weakening [Hirose, Shimamoto, 2005; Reches, Lockner, 2010]. In recent years, with further research, some authors paid more attentions to the influence of earthquake nucleation and fault geometry on fault sliding under nonplane and non-uniform stress conditions [Aochi, Fukuyama, 2002; Dieterich, Smith, 2009; Dieterich, Richards-Dinger, 2010]. These studies are essential to understand the mechanism of fast fault instability (or earthquake rupture) and to analyze earthquake. Also, these studies have become a footstone to probe earthquake mechanism. However, the further scientific question is how to combine these research results with the analysis of actual earthquake precursors. Although the long-, middle-, short- and impeding- term of earthquake prediction is widely used in concept, the standard of distinguishing these states is very vague. Here, we tried to conduct some discussions about it in the laboratory. For example, in a stress-strain curve, we defined that the sub-instable phase of a fault starts between peak stress and fast instability initiation. Thus, if the key window before fast fault instability is probably observed, the meta-instability phase would be identified [Ma et al., 2012, 2014; Ren et al., 2013; Ma, 2016]. We also found that fault nucleation and stress release initiated while the stress-strain 
curve deviates from linearity, and the deviation gradually increased as time elapse. Therefore, the key to solve the problem is to find the way to distinguish a strong deviation point from measured data and the characteristics of stress (or strain) release in a sub-instable phase, and to determine the starting point of stress (or strain) release, the critical size of nucleation zone and its critical slip distance of fault. In this paper, the characteristics of meta-instability phase will be analyzed by comparing far-field stress from pressing machine with multi-physical factors in the sample surface, including volume strain, shear strain and acoustic emission in the laboratory. Our previous experiments have proven that temperature increment is proportional to the volume strain increment under adiabatically elastic condition and have discussed temperature field properties during fault metainstability. Meanwhile, the corresponding finding showed that the temperature increases with volume compression while decreases with volume expansion in rocks. Here, as an example, we will continue to discuss the properties of meta-instability phase in volume strain for comparing the results from previous temperature observation.

\section{EXPERIMENTAL CONDITIONS, OBSERVATION METHOD AND DATA PROCESSING}

The experiments were performed using Fangshan granodiorite specimens ( $\mathrm{L}=300 \mathrm{~mm}, \mathrm{~W}=300 \mathrm{~mm}$, and $\mathrm{H}=50 \mathrm{~mm}$ ).
A straight fault was precut along the diagonal of the sample. In addition, 57 strain gauges (14 groups of strain rosettes with every three gauges) were pasted on the sample surface along the fault line to trace fault deformation. By calibration, the resolution of strain data was about $1.0 \mu \varepsilon\left(1 \mu \varepsilon=10^{-6}\right)$ with the sampling rate of $100 \mathrm{~Hz}$. Meanwhile, eight acoustic emission (AE) sensors were distributed on the specimen surface along the fault strike to record micro-rupture signals during loading. AE signals were recorded by the continuous sampling equipment at the rate of $3 \mathrm{MHz}$ and the sampling resolution of 16 bits (Fig. 1).

In the experiment, the displacement and load of specimen platens are applied by a two-way servo-controlled loading, and X-pressure is constantly kept at 5.0 MPa, while Y-direction is applied with the platen of the stable displacementcontrolled rate. Here, in terms of quasi-periodic stick-slip events, we select a typical one (the loading displacement rate is about 0.1 micrometer per second) to study the deformation characteristics during the fault meta-instability stage. The full differential stress-time plot of the event is shown in Fig. 2.

A complete stick-slip event shown in Fig. 2 lasts about $702 \mathrm{~s}$. The key time points during sample deformation are marked as L, M, N, O, A, B and $B_{2}$. Specifically, L-M represents the linear deformation phase, $\mathrm{M}-\mathrm{O}$ - the deviation phase, and $\mathrm{N}-\mathrm{O}$ - turns to the strong deviation phase corresponding

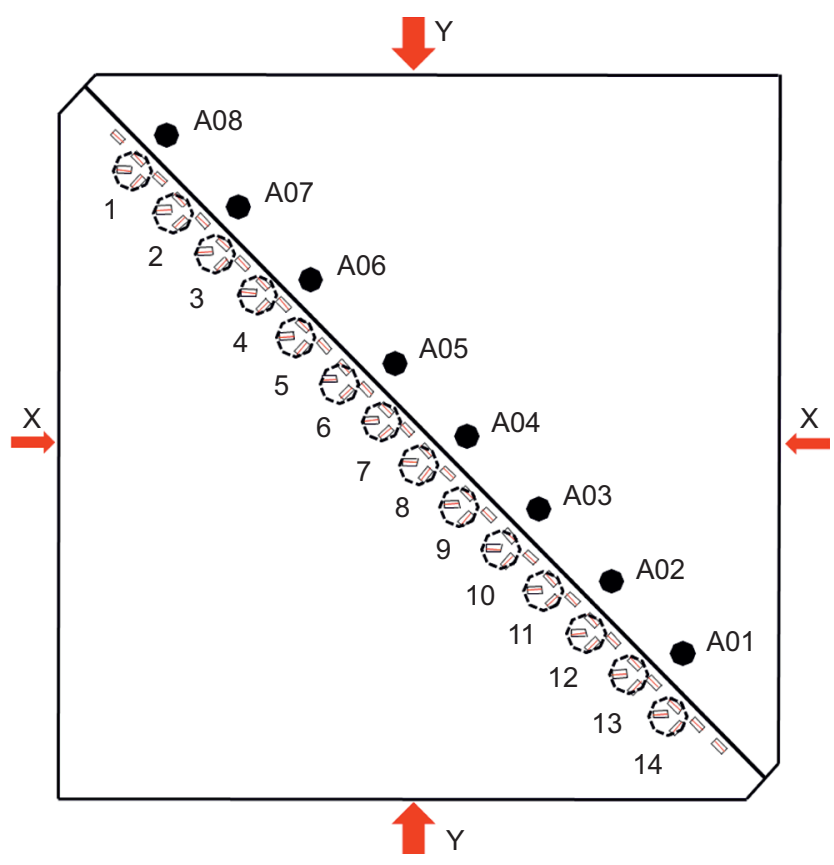

Fig. 1. Sketch of the specimen structure, observation points, and locations of important phenomena that occurred during the experiments.

Solid black line in the centre - fault that was precut along the diagonal of the specimen; thin black rectangles (red lines inside) - strain gauges; black dash-line circles (1 to 14) - strain tensor points along the fault; black solid circles (A01 to A08) - acoustic emission transducers.

Рис. 1. Схема, показывающая изучаемую структуру, расположение точек наблюдения и места, в которых в ходе экспериментов наблюдались важные явления.

Сплошная черная линия в центре - разлом, вырезанный по диагонали образца; прямоугольники, изображенные тонкими черными линиями (с красными линиями внутри), - тензодатчики; черные штриховые линии (1-14) - точки тензора деформации вдоль разлома; черные сплошные кружки (А01-А08) - преобразователи акустической эмиссии. 
to the previous linear phase. Due to a gradual increase of stress deviation, we take the time point as an identification one that the stress-time curve starts to turn flat (or non-increase), and is accompanied by a stress decrease, for determining the key time $\mathrm{N}$ of $688.0 \mathrm{~s}$. Thus, OAB is the meta-instability state as mentioned above. Point 0 represents the peak stress point $(694.0 \mathrm{~s})$, while OA (Point A is at $697.5 \mathrm{~s}$ ) is meta-instability Phase I where the release of quasi-static stress initiates, and $\mathrm{AB}$ is meta-instability Phase II for quasidynamic stress release. Here, we mark $B_{1}(699.5 \mathrm{~s})$ and $B_{2}$ (700.4 s) to explain the deformation difference between the two phases, respectively.

\section{THE STRAIN FIELD PROPERTIES IN THE META-INSTABILITY PHASES}

Fourteen groups of strain rosettes were used to investigate volume strain, maximum shear strain, normal strain and tangential strain. The strain rosettes (dash-line circles in Fig. 1) are arranged along the fault trace. The method for processing strain tensor data is explained in details in Appendix 1 . Since the trend change is similar between them, the evolution properties of volume strain (Fig. 3, a) and the maximum shear strain (Fig. 3, b) in the meta-instable phase are also similar. Thus, we focus on the analysis for the volume strain in this experiment.

In the linear deformation stage shown in Fig. 3, a, volume strain is generally compressive along the fault (the value of the compressive strain is positive). Since the stress curve deviates from the linearity (at $460.0 \mathrm{~s}$ ), volume strain curves start to diverge indifferent fault segments. Some of them begin to release (Point 12\&13); others continue to strengthen with strain accumulation. In addition, the differentiation becomes gradually distinct with the further deformation increase. The lower points of volume strain decrease, and the upper volume strain increases, but the change in the middle of the fault is much smaller. The overall accumulation trend of the strain turns flat.

The volume strain increases substantially and then it starts to decrease when the stage of strong deviation (688 s) starts. In order to highlight this stage of the strain characteristics, the time was set to zero point at $660.0 \mathrm{~s}$, and then the strain increment change in the stage was analyzed. Fig. 4, a-d shows the volume strain of all the measured points, and the upper, middle and lower segments after 660 s, respectively. The variation from that in Fig. 3 is that the accumulation trend of strain with the load increment disappears or becomes accelerative increment, or even decreases sometimes in different fault segments.

Fig. 4, b, indicates the strain increment curves versus time at the measured Points 14,13, and 12 in the lower fault segment. The three points of volume strain increments consequently decease as the linear deviation start from $660.0 \mathrm{~s}$. Among the points, volume strain at Point 14 releases (decreases) first at the maximum value, which is followed by Points 13 and 12. The strain value of Point 12 slightly increases as the value of Point 13 starts to decrease. Thus, the strain release process lasts from Point 14 to 12 , which implies that the growth process is from high to low volume

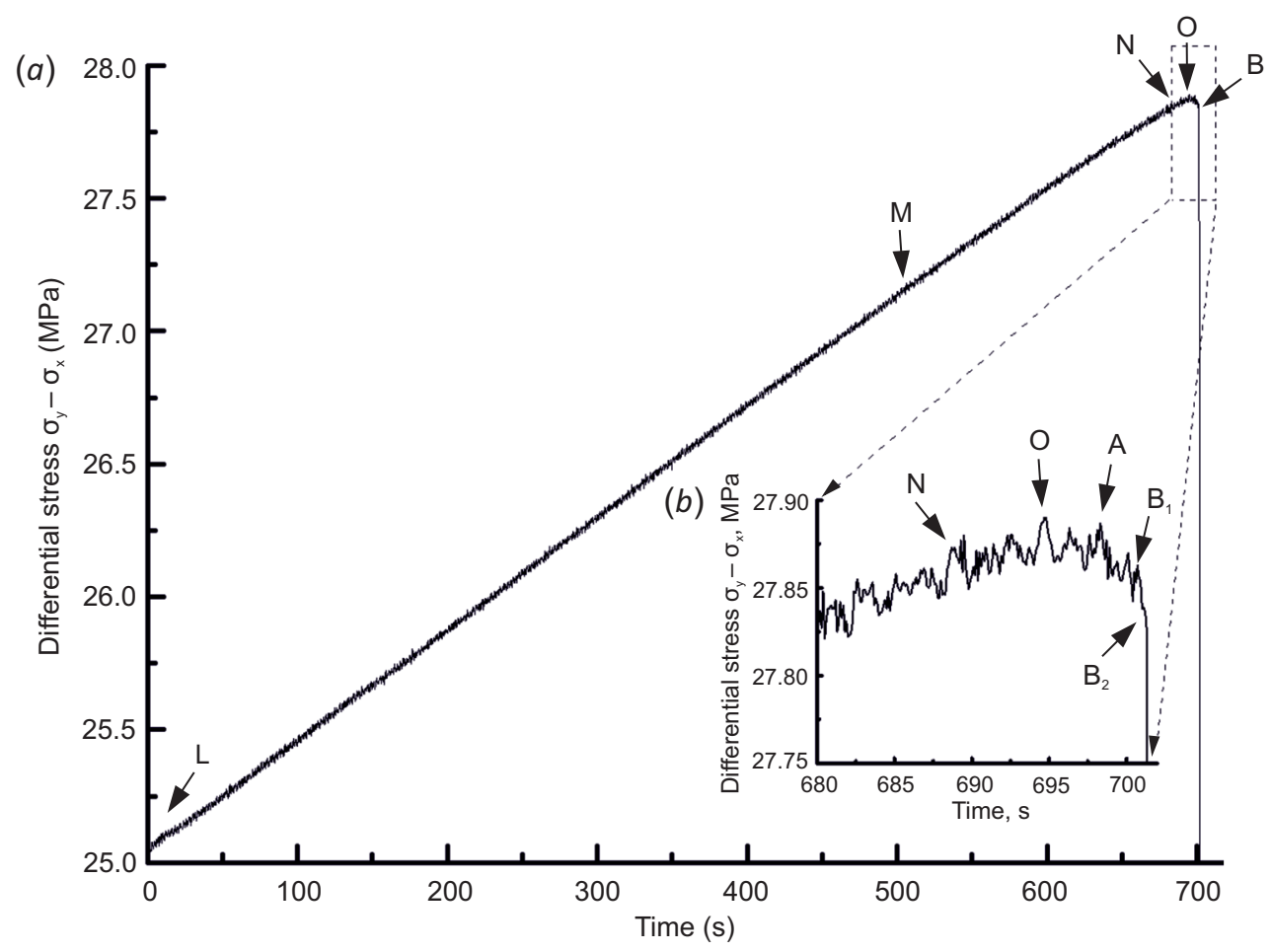

Fig. 2. Curves of the differential stress-time process $(a)$, and an enlarged sketch of the meta-instability stage $(b)$. Key time points are explained in the text.

Рис. 2. График дифференциального напряжения относительно времени (a) и увеличенный график стадии метанестабильности (b). См. пояснения в тексте. 
strain. The strains at Point 13 and 12 at first increase quickly until close to fault instability, and then drastically decrease. Consequently, the final instability occurs. Since the acute strain variations last for a short time span (less than $0.1 \mathrm{~s}$ ), all the measured points of strain values show a compressive type of strain increasing, which is defined as the compressive strain pulse. However, the pulse at Point 14 is not obvious. Moreover, the maximum change occurs at Point 12, and its local instability is occurs later in time than at other measured points.
The release of volume strain at Point 9, 8 and 7 in the middle of the fault segment occurs later than those in the lower segment, and the strain at Point 9 and 8 decreases at $665.0 \mathrm{~s}$, which is relatively earlier. Nevertheless, the release of volume strain at Point 7 increases at the same time (Fig. 4, c). After moment 0 (694.0 s), the volume strains at Point 9 and 8 drop at a much higher rate, accompanying by Point 7. After $697.5 \mathrm{~s}$, the volume strain at Point 9 drops down at a faster rate, while the strains at Points 8 and 7 drop down at a slower rate. It is similar to the strain evolution
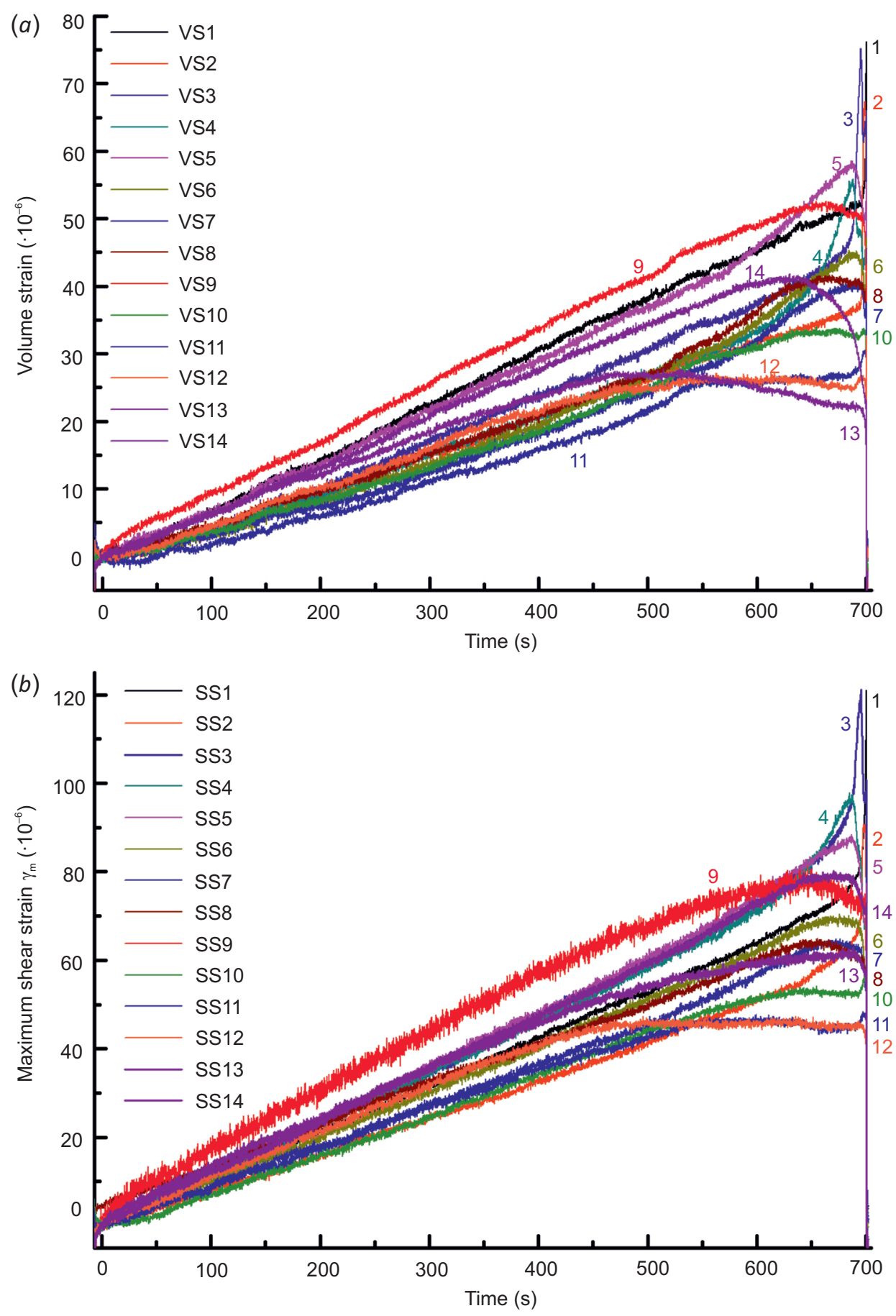

Fig. 3. Volume strain $(a)$ and maximum shear strain $(b)$ vs time.

Рис. 3. Зависимость объемной деформации $(a)$ и максимальной деформации сдвига $(b)$ от времени. 
process in the lower segment. As approaching close to the fast instability, the strain at Points 8 and 7 starts to further increase, and then the entire fault turns to the fast instability after the compressive strain pulse appears. The compressive strain pulse is the largest at Point 7, followed by Point 8, while it is not very obvious at Point 9.

The volume strain at Points 1, 2, 3, and 4 releases later in time than those in the upper fault segment. The value at Point 4 increases first, and is followed by Points 3, 2 and 1 (Fig. 4, d). At 688.0 s, the volume strain at Point 4 turns into a drop, but the neighboring Point 3 continues to increase. Similarly, the volume strain value at Point 2 rises, but declines at Point 3 . The same observation is found at Points 1 and 2. Those indicate the front-type of the strain release and adjustment. This situation is in a certain degree similar to the sliding self-healing model proposed in [Heaton, 1990], which shows that the rising time of fault dislocation is shorter than the total duration of an earthquake from the seismic wave data. Here, it is worthy to point out that this type of strain adjustment will extend at an accelerative fashion. The amplitude of compressive strain pulses at Point 1 is the largest, and the smallest at Point 4 close to instability.

In order to clearly illustrate the process of strain adjustment, Fig. 5, a shows the spatial-temporal evolution process in of volume strain at all the measured points along the fault. From 660.0 s to 702.0 s, the strain values at Points 14,9 , and 4 successively experience a strain drop, and the drop area gradually expands. Fault instability occurs after the time when the area and the amplitude of the volume strain drop develop to a certain value. It verifies the strain adjustment that the dynamic instability occurs after the nucleation zone grows up to a certain critical size [Ohnaka, 1992; Ma et al., 2002, 2003], and the area at volume strain rising is accompanied in turn by the corresponding dropping ones. In other words, the strains at Points 4, 3, 2, and 1 increase, but the strains drop at Points $14,9,8$, and 4.This case is similar to Fig. 4, d. The strain transition process appears gradually (a)

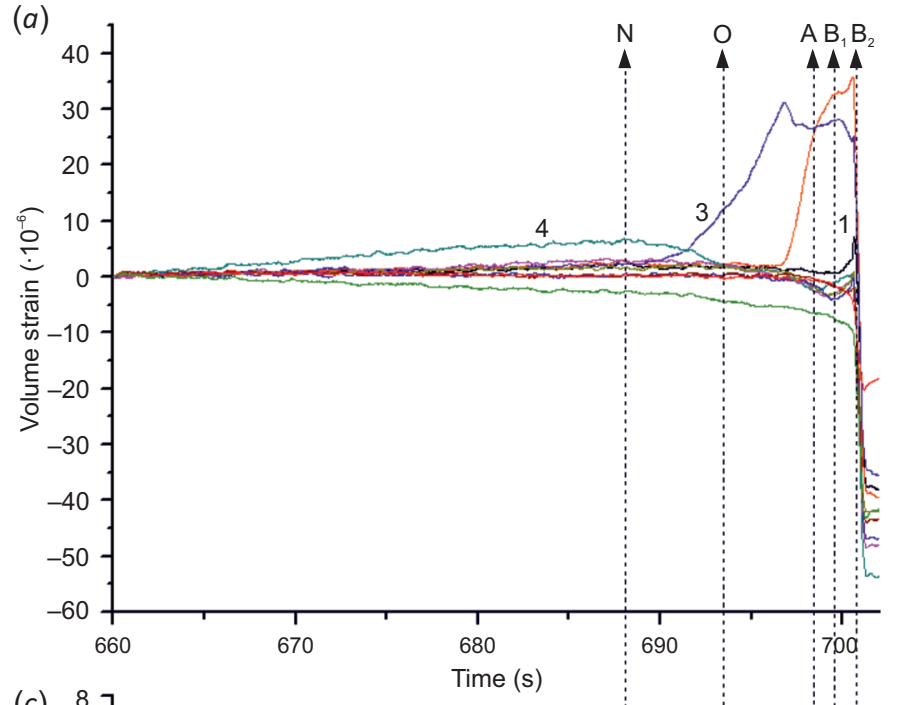

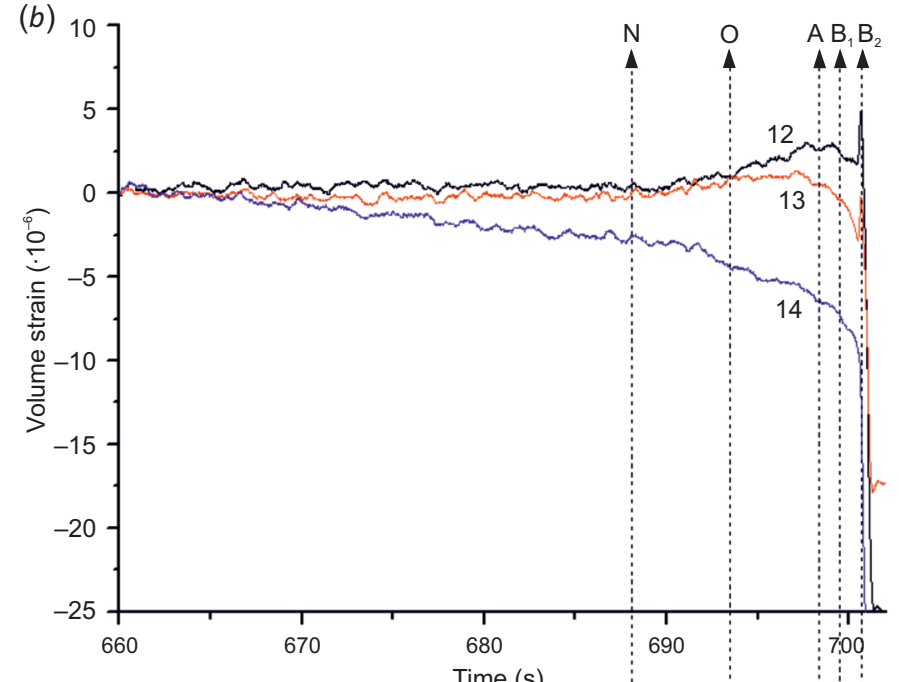

(d)

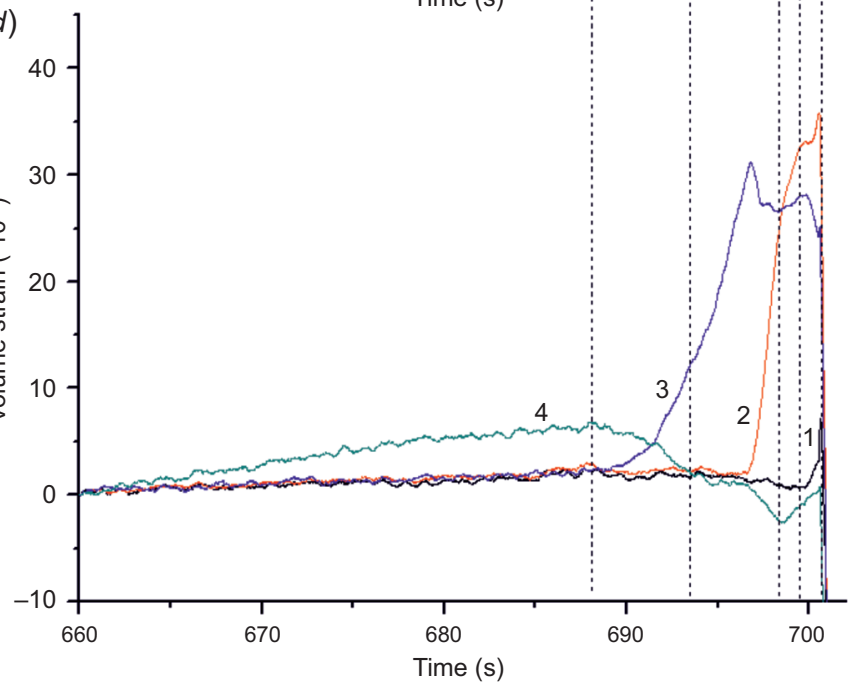

Fig. 4. Variations of volume strain increment at measured Points after $660 \mathrm{~s}$, and the process of strain adjustment in three fault segments. Numbers 1-14 - strain tensors.

Рис. 4. Изменение прироста объемной деформации в точках замера через 660 с и процесс регулировки деформации в трех сегментах разломов. Цифры 1-14 - тензоры деформации. 

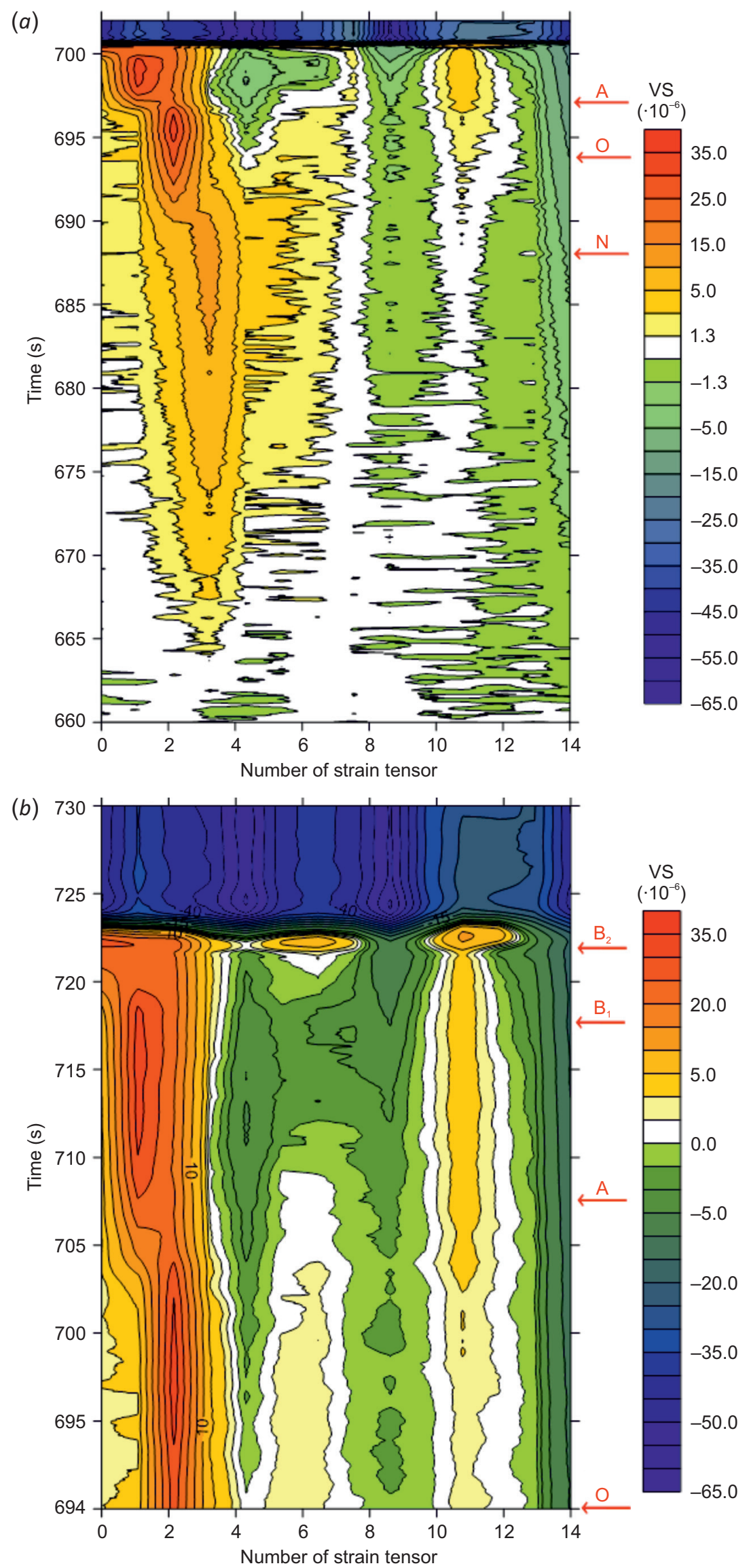

Fig. 5. Spatial-temporal diagram of volume strain at different measured points.

Рис. 5. Пространственно-временная диаграмма объемной деформации в разных точках замера. 
from Points 4, 3, 2 to 1 in the volume strain increment in Fig. 5, a. Fig. 5, b illustrates the volume strain changes versus time in different fault segments during the meta-instability state (after moment $\mathrm{O}$ of the peak stress). The amplitude of the volume strain drop increases after moment 0 , the rising area in volume strain migrates to the left, and a high gradient of strain zone forms between Points 4 and 3. In addition, in moment $\mathrm{B}_{1}$, a quasi-synchronization of abrupt strain change appears in different locations along the fault. Asynchronously compressive strain pulse consequently occurs in moment $\mathrm{B}_{2}$. It might be caused by a local release of volume strain due to the acceleration of local fault dislocation, which indicates direct rate-dependence of strain pulse. Besides, local instability appears about $0.1 \mathrm{~s}$ earlier at Points 4 and 9 than in both their outsides. It is also worth noting that this type of strain pulse is not observed in the far-field stress curve from the press, but only observed in the strain data along all the points near fault face. Clearly, it does not reflect the stress variation in the far field, but the deformation near the fault.

The phenomena shown in Fig. 5 can also be summarized as following: (1) the drop area of volume strain at Points 14, 9 and 4 successively extends from the lower to upper segment, i.e. from the low volume strain area to the high volume strain area. At the same time, the volume strain starts to rise at Points 4, 3, 2, and 1, successively. (2) The final instability occurs at Points 14 and 9, which is mainly associated with the energy release of the low volume strain areas within a small scale, but Points 4, 3, 2, 6, and 11 are still keep rising in the high volume strain areas. The former promotes the latter that is related to the entire fault instability. (3) In the whole deformation process, two kinds of strain adjustments take place. One occurs at Points 4, 3, 2, and 1, which belongs to a kind of steady front-type of strain change. Another is a dynamic strain adjustment about $0.1 \mathrm{~s}$ ahead of the entire instability. (4) The variation distribution of volume strain in different segments is distinguishable: the change content in the middle fault is minimum $(<10 \mu \varepsilon)$, and maximum $(>30 \mu \varepsilon)$ in the upper segment.

\section{VARIATIONS OF OTHER PHYSICAL PARAMETERS}

Some other observation techniques were used to analyze the features of fault meta-instability comparing to the strain observation in the experiment.

The digital image correlation (DIC) method was used in testing to analyze the change of the fault displacement against time with a high-speed camera [Zhuo et al., 2013, 2015]. The research results have revealed that the local slippage appeared in the same areas from 7 to 8 before moment 0 in this testing. In Fig. 1, the three initial prelsips occurred near strain measurement Points 14, 9, and 4, and the local slip zones gradually extend after moment 0 . The right lateral displacement zonesspeed up to expand after moment 0 . After a moment, expanding quasi-static displacement of the area occurs to the left before moment A,until quasi-dynamic extension dynamically starts at moment B. That indicates the initial areas of local fault slippage in accord with those of strain release. It reveals that the relaxation in volume strain along the fault is directly associated with the fault pre-slip.

Fig. 6 shows the waveforms of an instability event from a device for continuous recording of acoustic emission signals analyzed the sofware of Ae007 [Liu et al., 2009]. The waveforms mean that there is an $\mathrm{AE}$ event (induced by a micro-rupture or a small local preslip) in the fault. Red lines indicate the initial arrival time of each waveform. The difference in the initial arrival time represents the distance scale between the event and AE transducers (AE01 to AE08). The arrival time of Channel 7 is clearly earlier than that of other channels, and the amplitude of front-runner wave [Ellsworth, Beroza, 1995] is also the biggest and lasts about $100 \mu \mathrm{s}$. The arrival time of the front-runner wave and the transition process of fault instability are consistent. Also, the area is in accordance with a high gradient of strain zone near Point 3.

\section{DISCUSSION}

The external load was applied near to Point 1 at the upper part of the specimen. The volume strain here is minimum, but maximum at Point 14 in the lower part of the fault. Some locked zones are present along the fault strike because of the material heterogeneity and uneven symmetry surface. In testing, the initial slippages all appear in the areas of low volume strain, namely, the nucleation zones. With load increase, the drop of volume strain initiates in some fault segments, and the first one happens at Point 14 and gradually expands up. Subsequently, the volume strain release at Points 8 and 9 follows from the dynamic heterogeneity induced by the early sliding. In other words, it may be caused by the bending of the specimen and local contacts of the fault medium [Ben-David et al., 2010].

The drop and growth in volume strain along the fault line is close to fault instability. The feature is consistent with not only the fault slipping areas obtained by the DIC method [Zhuo et al., 2013, 2015], but also the temperature drop areas recorded by the temperature sensors before fault instability [Ma et al., 2012]. However, unlike the temperature variation, the volume strain abruptly jumps up (compressive strain pulse) before entire fault instability. The temperature drop is observed in a bending fault without this type of strain pulse under the same loading rate $(0.1 \mu \mathrm{m} / \mathrm{s})$ and data sampling rate (100 Hz [Ma et al., 2012]). The primary reason may be the difference in response speed of two physical factors to fault instability. The response speed of the strain sensor is about $10-20 \mathrm{~ms}$, which is so slow for the heat conduction.

The volume strain relaxation from independent measured points does not represent the coming of entire fault instability, but the average volume strain represents the overall stress level, which is associated with final fast instability. As mentioned before, Heaton [Heaton, 1990] noticed that the rising time of a fault dislocation is shorter than the total duration of an earthquake. This is because the slip time of a certain fault segment is obviously shorter than that of a whole fault. He proposed a self-healing model after the fault rupture front passes through. In our experiments, it is 


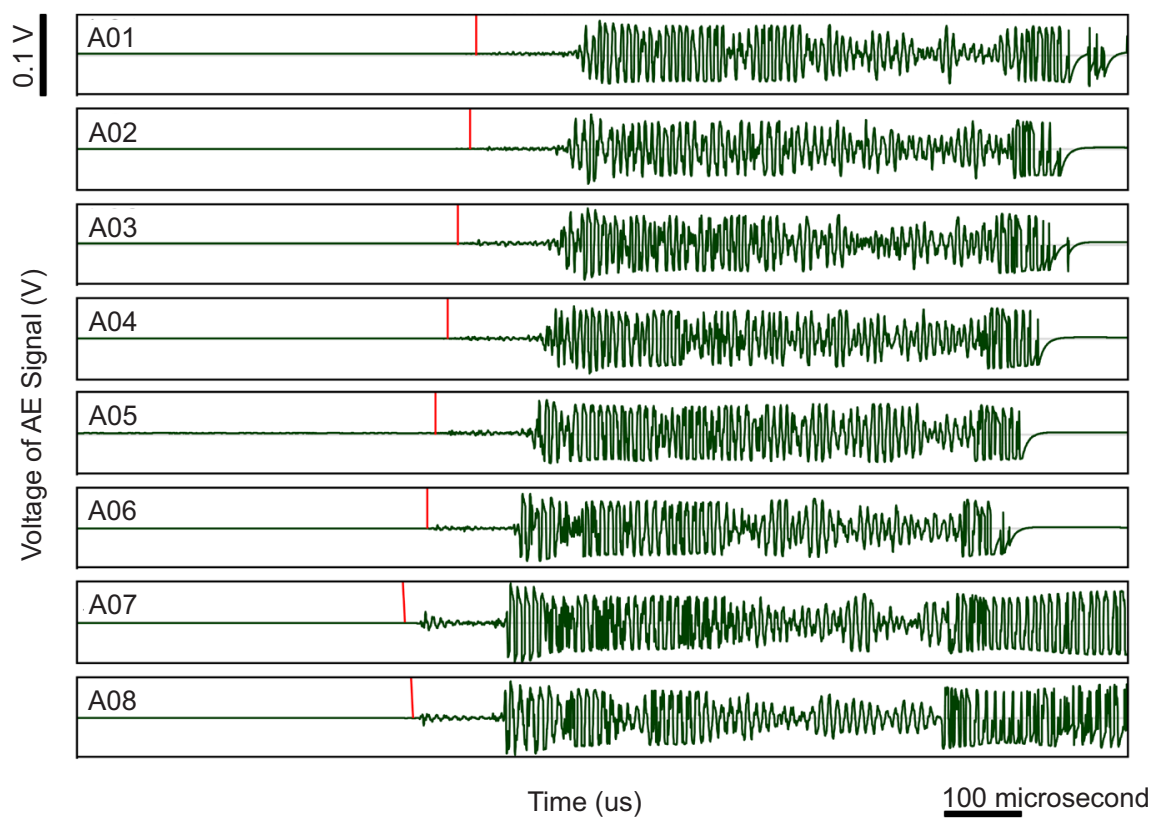

Fig. 6. Waveforms of an AE event recorded by AE transducers (A01 to A08).

Vertical red lines at each waveform curve mark the pick-up arrival time of the AE event. The length of the waveform window is 4096 sampling points.

Рис. 6. Волновые формы проявления акустической эмиссии по записям датчиков акустической эмиссии (А01-А08). Вертикальная красная линия на каждой кривой - время проявления акустической эмиссии. Длина окна волновой формы 4096 точек.

also shown that the phenomena exist not only in the expansion and self-healing of the seismic waves, but also in the spread of the slow strain wave.

If the partitions in high volume strain do not yet initiate after local fault instability appear those in low volume strain areas, only a creep event takes place without an accompanying strong earthquake (the speed of the strain front is about $0.006 \mathrm{~m} / \mathrm{s}$ ). As Ben-David described, that after the rupture nucleation, the super shear rupture will generate as long as it approaches to a high pre-stress zone [Ben-David et al., 2010], according to their experimental results. The high stress in the fault segment makes the rupture spread at a high speed (the speed of rupture front $>2 \mathrm{~m} / \mathrm{s}$ ) to induce a destructive earthquake. The strong instability has resulted in the interaction of low and high stress of tectonic zones. The research results for the 2011 Tohoku-Oki earthquake show that before a 7.3 magnitude of foreshock occurred in March 9, 2011, a series of small foreshocks grew at a quasi-static speed within 23 days (from $2 \mathrm{~km} /$ day to $5 \mathrm{~km} /$ day), but speeded up at the rate of quasi-dynamic extension after March 9, 2011 [Kato, 2012]. Besides, Ikuta [Ikuta et al., 2012] proved that the earthquake source area is a locked zone surrounded by a lot of 7-magnitude of earthquakes for many years, as shown by GPS data, and he observed that the largest coseismic displacement also happens at this location. Based on the discussion above, the condition for generation of a strong earthquake is associated with the two tectonic positions in high and low stress levels.

of course, the results presented in this paper are only to discuss the strain tensor in the plane stress state, not the plane strain state, because of the limits of our testing technique. In the future, we will try to solve the observation problem concerning the plane strain state to monitor changes in the shape of the ellipsoid of deformations inside a rock sample, i.e. to calculate the Lode - Nadai coefficient [Rebetskii et al., 2005].

\section{CONCLUSION}

On the basis of the experimental results, the instable process of a straight fault may be generally divided into the several states by strain measurement: linear accumulation (steady state) and linear deviation (sub-stability state) before peak stress, meta-instability state (i.e. nucleation phase, in laboratory) and fast instability (instability state) after peak stress. In the first state, the strain values increase linearly and slowly at all the measured points along the fault, and then the strain levels diverge after the linear deviation. Especially in meta-instability, the strain release in a few of areas consequently initiates, and the release rates are larger than strain accumulation ones during this stage. Finally, the entire instability happens along the fault with the fast increment and compressive pulse in the strain release areas.

The deformation differences between sub-stability (linear deviation) and meta-instability are as following: (1) since far-field stress experiences a linear deviation, the strain release areas appear in different areas along the fault, and the areas further extend in the strongly linear stress deviation state with a larger amplitude of strain release. At the same time, the strengthening areas of volume strain start 
to migrate, which characterizes a steady-state front-type of strain adjustment; (2) in the meta-instability state, the volume strain release areas grow faster, interconnect and gradually cross the entire fault. It is also taken as the synergy process of the fault activity which is clearly observed via the volume strain change.

Two types of tectonic zones form in a stick-slip event: the area of relatively high volume strain, and the area of relatively low volume strain, both located along the stressed fault. The former usually weakens at first and turns into local strain release, and the latter becomes the stress-locked part and induces fast instability. Besides, two instabilities appear along the fault. One is associated with the local release areas of low volume strain, which means fault pre-slip, a slow earthquake or a weak earthquake. Another is related to the release area with high volume strain, which means a strong earthquake, i.e., the entire fault instability. Furthermore, the former boosts the occurrence of the latter.

Meanwhile, two types of strain adjustments are observed by the strain measurement: the local front-type of strain adjustment that the local deformation areas grow from low to high strain since strain release initiates, and the compressive strain pulse that is caused by a sudden rising of volume strain close to the entire fault instability as the local release area extends up to certain scale. The former's adjustment gradually occurs along the fault within about $12 \mathrm{~s}$. The latter happens at a quasi-synchronization kind of dynamic strain adjustment within less than $0.1 \mathrm{~s}$ along different fault areas.

To sum up, the areas of relatively low volume strain should be paid more attention for evaluating the fault meta-instability state before fast slip instability. The areas of relatively high strain accumulation need be intensively observed to look for future earthquake epicenters.

\section{ACKNOWLEDGEMENTS}

The research is financially supported by the National Natural Science Foundation of China (grants No. 41911530111 and No. 41572181), the National Key R\&D Program of China (grant No. 2018YFC1503301) and the Basic Research Funds from Institute of Geology, China Earthquake Administration (grant No. IGCEA1203). We would specially like to give our appreciation to Prof. S.I. Sherman and Prof. S.A. Bornyakov, who have provided beneficial scientific suggestions during our cooperative work since 2011. We appreciate the comments and suggestions from the reviewers and the editors.

\section{REFERENCES}

Aochi H., Fukuyama E., 2002. Three-Dimensional Nonplanar Simulation of the 1992 Landers Earthquake. Journal of Geophysical Research: Solid Earth 107 (B2), 2035. https:// doi.org/10.1029/2000JB000061.

Ben-David O., Cohen G., Fineberg J., 2010. The Dynamics of the Onset of Frictional Slip. Science 330 (6001), 211-214. https://doi.org/10.1126/science.1194777.

Brace W.F., Byerlee J.D., 1966. Stick-Slip as a Mechanism for Earthquakes. Science 153 (3739), 900-992. https://doi. org/10.1126/science.153.3739.990.
Brace W.F., Byerlee J.D., 1970. California Earthquake: Why Only Shallow Focus? Science 168 (3939), 1573-1575. https://doi.org/10.1126/science.168.3939.1573.

Byerlee J.D., 1967. Frictional Characteristics of Granite under High Confining Pressure. Journal of Geophysical Research 72 (14), 3639-3648. https://doi.org/10.1029/JZ07 $2 \mathrm{i} 014 \mathrm{p} 03639$.

Byerlee J.D., 1978. Friction of Rocks. Pure and Applied Geophysics 116, 615-626. https://doi.org/10.1007/9783-0348-7182-2_4.

Chang J.C., Lockner D.A., Reches Z., 2012. Rapid Acceleration Leads to Rapid Weakening in Earthquake-Like Laboratory Experiments. Science 338, 101-105. https://doi.org/ 10.1126/science.1221195.

Dieterich J.H., 1978. Time Dependent Friction and the Mechanics of Stick-Slip. Pure and Applied Geophysics 116, 790-806. https://doi.org/10.1007/978-3-0348-71822_15.

Dieterich J.H., 1979. Modeling of Rock Friction: 1. Experimental Results and Constitutive Equations. Journal of Geophysical Research: Solid Earth 84 (B5), 2161-2168. https:// doi.org/10.1029/JB084iB05p02161.

Dieterich J.H., 1986. Model for the Nucleation of Earthquake Slip. In: Sh. Das, J. Boatwright, Ch.H. Scholz (Eds) Earthquake Source Mechanics. American Geophysical Union 37 (6). https://doi.org/10.1029/GM037p0037.

Dieterich J.H., 1992. Earthquake Nucleation of Faults with Rate and State Dependent Strength. Tectonophysics 211 (1-4), 115-134. https://doi.org/10.1016/0040-1951 (92) $90055-\mathrm{B}$.

Dieterich J.H., Richards-Dinger K.B., 2010. Earthquake Recurrence in Simulated Fault Systems. In: M.K. Savage, D.A. Rhoades, E.G.C. Smith, M.C. Gerstenberger, D. Vere-Jones (Eds), Seismogenesis and Earthquake Forecasting: The Frank Evison, Vol. II, 223-250. https://doi.org/10.1007/978-30346-0500-7_15.

Dieterich J.H., Smith D.E., 2009. Nonplanar Faults: Mechanics of Slip and Off-Fault Damage. Pure and Applied Geophysics 166 (10), 1799-1815. https://doi.org/10.1007/ 978-3-0346-0138-2_12.

Ellsworth W.L., Beroza G.C., 1995. Seismic Evidence for an Earthquake Nucleation Phase. Science 268, 851-855. https://doi.org/10.1126/science.268.5212.851.

Fukuyama E., 2009. Fault-Zone Properties and Earthquake Rupture Dynamics. International Geophysics 94, 1-13. https://doi.org/10.1016/S0074-6142(08)00001-6.

He Changrong, 2000. Numerical Simulation of Earthquake Nucleation and Precursory Process in Slipping Fault Planes. Earthquake Research in China 16 (1), 1-13 (in Chinese).

He Changrong, 2003. The Interaction of a Double Slider System under Rate- and State-Dependent Friction Law. Science in China (Series D) 33 (Suppl.), 53-59 (in Chinese).

He Chang-Rong, Tao Qing-Feng, Wang Ze-Li, 2004. Frictional Strength and Rate Dependence of Gouge under Elevated Temperature and Pressure. Seismology and Geology 26 (3), 450-459 (in Chinese).

He Changrong, Wang Zeli, Yao Wenming, 2007. Frictional Sliding of Gabbro Gouge under Hydrothermal Conditions. 
Tectonophysics 445 (3-4), 353-362. https://doi.org/10. 1016/j.tecto.2007.09.008.

He Changrong, Yao Wenming, Wang Zeli et al., 2006. Strength and Stability of Frictional Sliding of Gabbro Gouge at Elevated Temperatures. Tectonophysics 427 (1-4), 217229. https://doi.org/10.1016/j.tecto.2006.05.023.

Heaton T.H., 1990. Evidence for and Implications of SelfHealing Pulses of Slip in Earthquake Rupture. Physics of the Earth and Planetary Interiors 64 (1), 1-20. https://doi.org/ 10.1016/0031-9201(90)90002-F.

Hirose T., Shimamoto T., 2005. Slip-Weakening Distance of Faults during Frictional Melting as Inferred from Experimental and Natural Pseudotachylytes. Bulletin of the Seismological Society of America 95 (5), 1666-1673. https:// doi.org/10.1785/0120040131.

Ikuta R., Satomura M., Fujita A. et al., 2012. A Small Persistent Locked Area Associated with the 2011 Mw 9.0 TohokuOki Earthquake Deduced from GPS Data. Journal of Geophysical Research: Solid Earth 117, B11408. https://doi. org/10.1029/2012JB009335.

Kato N., 2012. Dependence of Earthquake Stress Drop on Critical Slip-Weakening Distance. Journal of Geophysical Research: Solid Earth 117, B01301. https://doi.org/10. 1029/2011JB008359.

Liu Liqiang, Lei Xinglin, 2003. An Observation System of Acoustic Emission Signal Based on Ultra High Speed Parallel Network. Seismology and Geology 25 (3), 477-479 (in Chinese).

Liu Peixun, Liu Liqiang, Huang Yuanmin et al., 2009. Robust Arithmetic for Acoustic Emission Location. Chinese Journal of Rock Mechanics and Engineering 28 (S1), 27602764 (in Chinese).

Ma Jin, 2016. On «Whether Earthquake Precursors Help for Prediction Do Exist». Chinese Science Bulletin 61 (4-5), 409-414 (in Chinese). https://doi.org/10.1360/N97201501239.

Ma J., Guo Y., Sherman S.I., 2014. Accelerated Synergism along a Fault: A Possible Indicator for an Impending Major Earthquake. Geodynamics \& Tectonophysics 5 (2), 387-399. https://doi.org/10.5800/GT-2014-5-2-0134.

Ma J., Sherman S.I., Guo Y.S., 2012. Identification of MetaInstable Stress State Based on Experimental Study of Evolution of the Temperature Field during Stick-Slip Instability on a $5^{\circ}$ Bending Fault. Science China Earth Sciences 55, 869881. https://doi.org/10.1007/s11430-012-4423-2.

Ma Shengli, Liu Liqiang, Ma Jin et al., 2003. An Experimental Study on the Nucleation Process of Instable Slip for Homogenous and Heterogeneous Fault. Science in China (Series D) 33 (Suppl.), 45-52 (in Chinese).

Ma Shengli, Ma Jin, Liu Liqiang, 2002. Experimental Evidence for Earthquake Nucleation Phase. Chinese Science Bulletin 47 (5), 387-391 (in Chinese).

Moore D.E., Rymer M.J., 2007. Talc-Bearing Serpentinite and the Creeping Section of the San Andreas Fault. Nature 448, 795-797. https://doi.org/10.1038/nature06064.

Ohnaka M., 1992. Earthquake Source Nucleation: A Physical Model for Short-Term Precursors. Tectonophysics 211(1-4), 149-178. https://doi.org/10.1016/0040-1951(92)90057-D.
Ohnaka M., Akatsu M., Mochizuki H. et al., 1997. A Constitutive Law for the Shear Failure of Rock under Lithospheric Conditions. Tectonophysics 277 (1-3), 1-27. https://doi. org/10.1016/S0040-1951(97)00075-9.

Ohnaka M., Kuwahara Y., 1990. Characteristic Feature of Local Breakdown near a Crack-Tip in the Transition Zone from Nucleation to Unstable Rupture during Stick-Slip Shear Failure. Tectonophysics 175 (1-3), 197-220. https://doi. org/10.1016/0040-1951(90)90138-X.

Ohnaka M., Kuwahara Y., Yamamoto K., 1987. Constitutive Relation between Dynamic Physical Parameters near a Tip of the Propagating Slip Zone during Stick-Slip Shear Failure. Tectonophysics 144 (1-3), 109-125. https://doi. org/10.1016/0040-1951(87)90011-4.

Peselnic L., Dieterich J.H., Mjachkin V.I., Sobolev G.A., 1976. Variation of compressional velocities in simulated fault gouge under normal and direct shear stress. Geophysical Research Letters 3 (7), 369-372. https://doi.org/10.1029/ GL003i007p00369.

Rebetskii Yu. L., Lementueva R.A., D’yaur et al., 2005. Subordination of Misrostructure Deformations and Brittle Macrodestruction. Doklady Earth Sciences 403 (5), 812-815.

Reches Z., Lockner D.A., 2010. Fault Weakening and Earthquake Instability by Powder Lubrication. Nature 467, 452455. https://doi.org/10.1038/nature09348.

Ren Y.-Q., Liu P.-X., Ma J. et al., 2013. An Experimental Study on Evolution of the Thermal Field of En Echelon Faults during the Meta-Instability Stage. Chinese Journal of Geophysics 56 (5), 612-622. https://doi.org/10.1002/cjg2.20057.

Rice J.R., 2006. Heating and Weakening of Faults during Earthquake Slip. Journal of Geophysical Research: Solid Earth 111, B05311. https://doi.org/10.1029/2005JB00 4006.

Rice J.R., Ruina A.L, 1983. Stability of Steady Frictional Slipping. Journal of Applied Mechanics 50 (2), 343-349. https://doi.org/10.1115/1.3167042.

Ruina A.L., 1983. Slip Instability and State Variable Friction Laws. Journal of Geophysical Research: Solid Earth 88 (B12), 10359-10370. https://doi.org/10.1029/JB088i B12p10359.

Scholz C.H., 1988. The Critical Distance for Seismic Faulting. Nature 336, 761-763. https://doi.org/10.1038/ $336761 \mathrm{a} 0$.

Zhuo Y.Q., Guo Y.S., Ji Y.T. et al., 2013. Slip Synergism of Planar Strike-Slip Fault during Meta-Instable State: Experimental Research Based on Digital Image Correlation Analysis. Science China: Earth Sciences 56, 1881-1887. https://doi.org/10.1007/s11430-013-4623-4.

Zhuo Y.S., He C.R., 2009. The Rheological Structures of Crust and Mechanics of High-Angle Reverse Fault Slip for Wenchuan Ms8.0 Earthquake. Chinese Journal of Geophysics 52 (2), 474-484 (in Chinese).

Zhuo Y.Q., Ma J., Guo Y.S. et al., 2015. Identification of the Meta-Instability Stage via Synergy of Fault Displacement: An Experimental Study Based on the Digital Image Correlation Method. Physics and Chemistry of the Earth, Parts A/B/C 85-86, 216-224. https://doi.org/10.1016/j.pce.20 15.03.002. 


\section{APPENDIX 1}

Based on elastic mechanics, if three directions of the strain values (compression is positive) are measured at any point in orthogonal coordinates, as shown in Fig. A-1, Equation 1 can be produced:

$$
[A]\{\varepsilon\}=\left\{\varepsilon_{\theta}\right\},
$$

where $\{\varepsilon\}=\left[\begin{array}{lll}\varepsilon_{x} & \varepsilon_{y} & \gamma_{x y}\end{array}\right]^{T}$,

$$
\begin{aligned}
& \left\{\varepsilon_{\theta}\right\}=\left[\varepsilon_{a} \varepsilon_{b} \varepsilon_{c}\right]^{T}, \\
& {[A]=\left[\begin{array}{l}
\cos ^{2} \theta_{a} \sin ^{2} \theta_{a}-\sin \theta_{a} \cos \theta_{a} \\
\cos ^{2} \theta_{b} \sin ^{2} \theta_{b}-\sin \theta_{b} \cos \theta_{b} \\
\cos ^{2} \theta_{c} \sin ^{2} \theta_{c}-\sin \theta_{c} \cos \theta_{c}
\end{array}\right] .}
\end{aligned}
$$

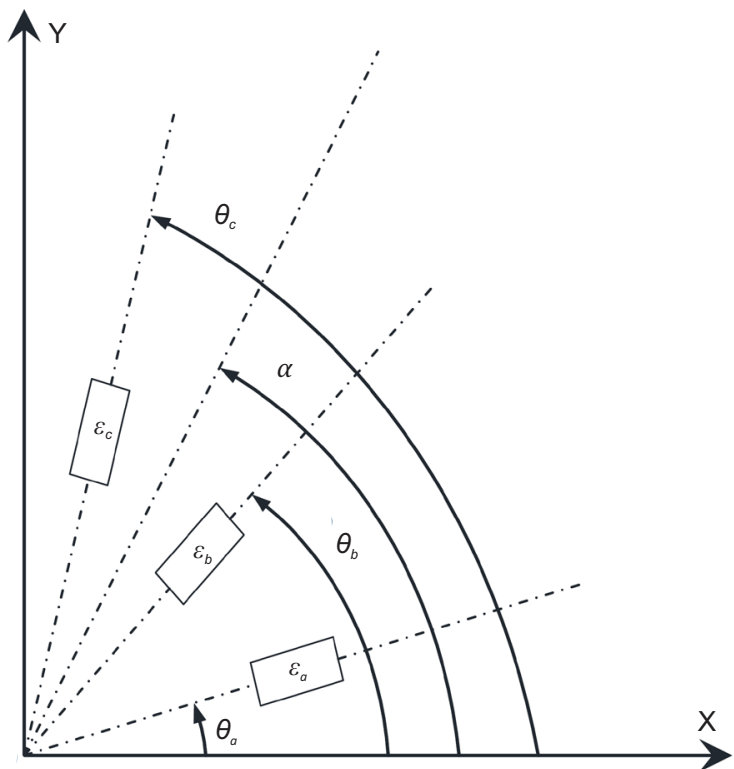

Fig. A-1. Sketch diagram for strain tensor calculation.

Рис. A-1. Схема для расчета тензора деформации.

Plane-strain components $\varepsilon_{x^{\prime}} \varepsilon_{y^{\prime}} \gamma_{x y}$ can be calculated at the specific point, and the principal strain tensor (in this article, take the compressive strain as a positive value, $\theta$ is positive on a counterclockwise) is also obtained. Besides, maximum and minimum principal strain, maximum shear strain and body strain can be calculated by the following equations, respectively:

$$
\begin{aligned}
& \left.\begin{array}{l}
\varepsilon_{1} \\
\varepsilon_{2}
\end{array}\right\}=\frac{\varepsilon_{x}+\varepsilon_{y}}{2} \pm \frac{1}{2} \sqrt{\left(\varepsilon_{x}-\varepsilon_{y}\right)^{2}+\gamma_{x y}^{2}}, \\
& \gamma_{\max }=\varepsilon_{1}-\varepsilon_{2}=\sqrt{\left(\varepsilon_{x}-\varepsilon_{y}\right)^{2}+\gamma_{x y}^{2}}, \\
& \varepsilon_{v}=\varepsilon_{x}+\varepsilon_{y} .
\end{aligned}
$$

In addition, the normal strain and shear strain are also calculated according to the coordinate transformation equation for the plane strain state.

$$
\begin{gathered}
\varepsilon_{\alpha}=\frac{\varepsilon_{x}+\varepsilon_{y}}{2}+\frac{\varepsilon_{x}+\varepsilon_{y}}{2} \cos 2 \alpha+\frac{x y}{2} \sin 2 \alpha, \\
\gamma_{\alpha}=-\left(\varepsilon_{x}-\varepsilon_{y}\right) \sin 2 \alpha+\gamma_{x y} \cos 2 \alpha .
\end{gathered}
$$

In other words, the normal strain and tangential strain are analyzed in the directions which are perpendicular to and parallel to the faults, respectively. As $\alpha$ is the inclined angle of the fault, the shear strain and the normal strain along the fault strike and the normal direction can be calculated, respectively, based on Equation 3 . 


\section{YANSHUANG GUO}

$\mathrm{PhD}$

State Key Laboratory of Earthquake Dynamics, Institute of Geology, China Earthquake Administration Jia 1, Huayanli, Chaoyang Dist., Beijing 100029, China e-mail: guoysh@ies.ac.cn

ORCID: 0000-0001-6645-4011

\section{YANQUN ZHUO}

$\mathrm{PhD}$

State Key Laboratory of Earthquake Dynamics, Institute of Geology, China Earthquake Administration Jia 1, Huayanli, Chaoyang Dist., Beijing 100029, China e-mail: zhuoyq@ies.ac.cn ORCID: 0000-0002-8503-5733

\section{PEIXUN LIU}

B.A.

State Key Laboratory of Earthquake Dynamics, Institute of Geology, China Earthquake Administration Jia 1, Huayanli, Chaoyang Dist., Beijing 100029, China e-mail: liupeixun@sina.com

\section{SHUNYUN CHEN}

$\mathrm{PhD}$

State Key Laboratory of Earthquake Dynamics, Institute of Geology, China Earthquake Administration Jia 1, Huayanli, Chaoyang Dist., Beijing 100029, China e-mail: chenshy@ies.ac.cn ORCID: 0000-0003-3886-5328

\section{JIN MA}

$\mathrm{PhD}$

State Key Laboratory of Earthquake Dynamics, Institute of Geology, China Earthquake Administration Jia 1, Huayanli, Chaoyang Dist., Beijing 100029, China ORCID: 0000-0001-8593-7027

\section{ЮАНШУАН ГУО}

$\mathrm{PhD}$

Государственная центральная лаборатория динамики землетрясений, Институт геологии, Администрация по землетрясениям Китая 100029, г. Пекин, Китай

\section{янцюнь чжУо}

$\mathrm{PhD}$

Государственная центральная лаборатория динамики землетрясений, Институт геологии, Администрация по землетрясениям Китая 100029, г. Пекин, Китай

\section{ПЭЙксУнь Лю}

B.A.

Государственная центральная лаборатория динамики землетрясений, Институт геологии, Администрация по землетрясениям Китая 100029, г. Пекин, Китай

\section{ШУНЬЮНЬ ЧЕН}

$\mathrm{PhD}$

Государственная центральная лаборатория динамики землетрясений, Институт геологии, Администрация по землетрясениям Китая 100029, г. Пекин, Китай

\section{ЦЗИНЬ МА}

$\mathrm{PhD}$

Государственная центральная лаборатория динамики землетрясений, Институт геологии, Администрация по землетрясениям Китая 100029, г. Пекин, Китай 